\title{
Characterization, Classification and Evaluation of Cashew Growing Soils in Coastal Odisha for Sustainable Production
}

\author{
R. Srinivasan ${ }^{1 *}$, S.K. Singh ${ }^{2}$, D.C. Nayak ${ }^{3}$ and L.G.K. Naidu ${ }^{1}$ \\ ${ }^{\prime} I C A R$ - National Bureau of Soil Survey and Land Use Planning, Regional Centre, \\ Hebbal, Bangaluru-560024, India \\ ${ }^{2}$ ICAR-National Bureau of Soil Survey and Land Use Planning, Amravati Road, \\ Nagpur-440 033, Maharashtra, India \\ ${ }^{3}$ ICAR-National Bureau of Soil Survey and Land Use Planning, Regional Centre, Salt lake, \\ Kolkata-700091, West Bengal, India
}

\begin{abstract}
Four major soil series (Jharokuali, Kumaradapalli, Ranibara and Kantiagada) representing the cashew growing soils in coastal Odisha, which are developed from different parent materials were studied for their morphological, physico-chemical properties and their suitability for cashew production. Soils are moderately deep to very deep, well drained, texture varied from sand to sandy clay. The soils are slightly acidic to moderately alkaline in nature. A cation exchange capacity is low. Plant available nutrients status of soils are low in N, low to high in available $\mathrm{P}$ and $\mathrm{K}$. The DTPA-extractable $\mathrm{Fe}, \mathrm{Cu}$ and $\mathrm{Mn}$ were sufficient. Available $\mathrm{Zn}$ is sufficient in surface horizons while deficient in subsoils. The soils at the order level are classified as Alfisols and Entisols at sub group level as Typic Rhodustalfs, Typic Haplustalfs and Typic Ustipsamments. Interpretative groupings for Land Capability, Land Irrigability and Suitability were assessed and identified soil related constraints and suggested appropriate managements measures to improve Cashew productivity.
\end{abstract}

Keywords: Characterization, evaluation, nutrients, cashew and coastal soils

\section{Introduction}

Cashew (Anacardium occidentale L.) belongs to the family Anacardiaceae, considered to be native of Brazil and is now found in many tropical areas. Cashew is grown in India, Brazil, Vietnam, Tanzania, Mozambique, Indonesia, Sri Lanka and other tropical Asian and African countries. The major commercial cultivation in India is confined to eight states viz., Andhra Pradesh, Goa, Karnataka, Kerala, Maharashtra, Odisha, Tamil nadu and West Bengal (www.cashew.res.in). At present in India, among the various agri-horticultural commodities involved in the global trade, cashew has attained a prominent place by providing significant contribution to Indian exchequer ranking among the ten top agriculture exports contributing nearly $0.35 \%$ of the total export earnings of the country. Cashew occupies an area of 9.45 lakh ha with production of 6.53 lakh MT of raw nut as on 2012-13 with an average productivity of $720 \mathrm{~kg} \mathrm{ha}^{-1}$. The current share of cashew production in India accounts for

*Corresponding Author Email: srinivasan.surya@gmail.com
$23 \%$ of the global production. A large number of small and marginal farmers, especially living on the coastal belts of India, depend on cashew for their livelihood.

Among the different states Odisha is the third largest cashew nut producing state and accounts for $11.4 \%$ of the total production in the country. The production of cashew nut is about $0.09 \mathrm{~m}$ MT from an area of $0.17 \mathrm{~m}$ ha having productivity of $0.35 \mathrm{MT} /$ ha during 2013-14 (www.nhm.nic.in). The average productivity of cashew in India and Odisha is 0.90 and 0.61 ton/ha/year respectively as against the target of 1 ton/ha/year. Low yields are due to poor management of land and soil resources. Hence there is a need to carry out detailed soil characterization which will form as base information for improving cashew production. Lekwa et al. (2004) reiterated that soil characterization provides the basic information necessary to create functional soil classification schemes and assess soil fertility in order to unravel some unique soil problems in an ecosystem.

The general notion is that "cashew is very modest in its soil requirements and can adapt to varying soil conditions 
without impairing productivity". While cashew can be grown in poor soils, but its performance would be much better on good soils. The best soils for cashew are deep and well-drained sandy loam without a hard pan in sub soil. Cashew also thrives on pure sandy soils, although mineral deficiencies are more likely to occur. Water stagnation and flooding are not congenial for cashew. Heavy clay soils with poor drainage and soils with $\mathrm{pH}$ more than 8.0 are not suitable for cashew cultivation. Excessive alkaline and saline soils also do not support its growth. Red sandy loam, lateritic soils and coastal sands with slightly acidic $\mathrm{pH}$ are best for cashew (Ghosh and Bose 1986).

In sustainable farming, risk is minimized by matching crop requirements to land qualities. This is the role of land evaluation and it implies a process of prediction (Udoh, 2015). One of the efforts to increase productivity is planting the crop only on suitable land. Land suitability analysis is a method generally used in site selection. The proper site selection should be established before any large scale development. Several methods have been developed in land suitability analysis, either qualitative or quantitative (George, 2005). Appropriate criteria should reflect the production, as the use of inappropriate criteria may cause errors in the diagnosis of land being evaluated. The use of inappropriate criteria under certain circumstances assessment often does not reflect the factual growth in the field as well as the production. Therefore a case study was undertaken in part of coastal Odisha to examine the soils, characterize, classify and evaluate major cashew growing soils to suggest management masures for better production.

\section{Materials and Methods}

A case study was taken up during 2014-15 in Ganjam block of Ganjam district, Odisha which is located (Fig. 1) in eastern part of the state, covering an area of 21,612 ha. Detailed soil survey was carried out on 1: 10,000 scale by using base map prepared from remote sensing satellite data (1RS-P6 LISS IV) in conjunction with the village cadastral map and survey of India (SOI) topo-sheets for physiographic delineation. Profile observations were demarcated to cover all the major cashew growing landforms of the coastal system. Totally, 46 representative pedons were studied. Soil pits were excavated in each landform for describing morphological characteristics (Soil Survey Staff 2010). Major variables in site characteristics were slope (Table 1), depth and soil colour. Soil colour was examined by using Munsell color chart. The collected soil samples were air dried, grounded and processed by sieving and labeled for soil analysis

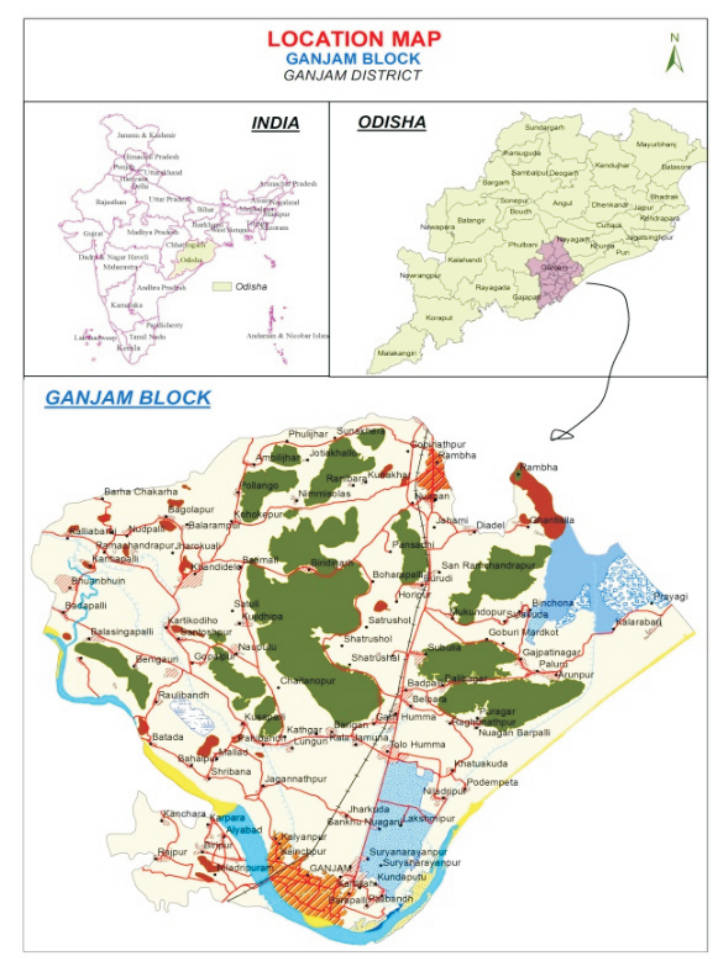

Fig. 1 Location of Study area 
Table 1. Site characteristics

\begin{tabular}{|c|c|c|c|c|c|c|c|}
\hline Series & $\begin{array}{c}\text { Area } \\
\text { covering } \\
\text { (ha) }\end{array}$ & Land form & $\begin{array}{l}\text { Slope } \\
(\%)\end{array}$ & Drainage & Erosion & Management & $\begin{array}{c}\text { Average } \\
\text { Cashew } \\
\text { Production } \\
\text { (Kg/ha) }\end{array}$ \\
\hline Jharokuali & 337 & $\begin{array}{l}\text { Moderately } \\
\text { sloping upland }\end{array}$ & $3-5$ & Well & Severe (S3) & $\begin{array}{c}\text { Low } \\
\text { (No inputs) }\end{array}$ & 728 \\
\hline Kumaradapalli & 671 & $\begin{array}{l}\text { Moderately } \\
\text { sloping foothill }\end{array}$ & $1-3$ & Well & $\begin{array}{l}\text { Moderate } \\
\text { (S2) }\end{array}$ & Medium & 864 \\
\hline Ranibara & 1511 & $\begin{array}{l}\text { Moderately } \\
\text { sloping foothill }\end{array}$ & $3-5$ & Well & Severe (S3) & $\begin{array}{c}\text { Low } \\
\text { (No inputs) }\end{array}$ & 620 \\
\hline Kantiagada & 2006 & $\begin{array}{l}\text { Gently sloping } \\
\text { coastal plain }\end{array}$ & $3-5$ & $\begin{array}{l}\text { Somewhat } \\
\text { excessive }\end{array}$ & Severe (S3) & $\begin{array}{c}\text { Low } \\
\text { (No inputs) }\end{array}$ & 635 \\
\hline
\end{tabular}

The soil samples were analysed in the laboratory for physical and chemical parameters using standard procedures. Particle-size distribution was determined by the international pipette method. Soil $\mathrm{pH}$ and $\mathrm{EC}$ were determined using the standard procedures described by Page et al. (1982). Soil organic carbon was determined by the wet oxidation method of Walkley and Black (1934). Cation exchange capacity (CEC) was determined using $1 \mathrm{~N}$ ammonium acetate at $\mathrm{pH}$ 7.0, whereas, base saturation was calculated as sum of bases divided by CEC and multiplied by 100. Exchangeable calcium $(\mathrm{Ca})$ and magnesium $(\mathrm{Mg})$ were determined by using Ethylene diamine tetra acetic acid (EDTA) titration (Jackson, 1973). These exchangeable acid cations were extracted using $1.0 \mathrm{~N} \mathrm{KCl}$ and total exchangeable acidity was determined by titrating with standard alkali $(\mathrm{NaOH})$ solution (Sarma et al. 1987). The available nitrogen was estimated through alkaline permanganate method as suggested by Subbiah and Asija (1956). Available phosphorus in soil was determined calorimetrically following ascorbic acid reduction method as outlined by Bray and Kurtz (1945). Available potassium was estimated by flame photometer after extraction with Neutral normal ammonium acetate solution ( $\mathrm{pH}$ 7.0). The available micronutrients $(\mathrm{Fe}, \mathrm{Mn}, \mathrm{Cu}$ and $\mathrm{Zn}$ ) were extracted using DTPA (Lindsay and Norvell, 1978) and their concentrations were determined using atomic absorption spectrophotometer. The soils were classified as per guidelines given in Key to Soil Taxonomy (Soil Survey Staff 2010). Land capability classes (LCC), land irrigability classes (LIC) were assigned (Table 6) following IARI soil survey manual (AISLUS, 1970). Soil- site suitability criteria developed for cashew was used to group soils in to different suitability classes (Naidu et al. 2006).

\section{Results and Discussion}

The climatic characteristics, soil properties and interpretative groups are discussed below Climate of the area

The Study area experiences sub-tropical to subhumid climate with average annual rainfall of $1403 \mathrm{~mm}$, maximum received during south-west monsoon from June to September (Table 2). The mean annual temperature varies from 26 to $28^{\circ} \mathrm{C}$ with mean summer temperature varying from 31 to $35^{\circ} \mathrm{C}$. The mean winter temperature ranges between 21 to $23^{\circ} \mathrm{C}$. The soil temperature regime is "hyperthermic" and the soil moisture regime is "ustic". 
Table 2. Prevailing climatic condition of the study area

\begin{tabular}{lcccc}
\hline \multirow{2}{*}{ Months } & \multicolumn{2}{c}{ Temperature $\left({ }^{\circ} \mathbf{C}\right)$} & $\begin{array}{c}\text { Mean Rainfall } \\
(\mathbf{m m})\end{array}$ & RH (\%) \\
\cline { 2 - 3 } & Min. & Max. & 0 & 76 \\
\hline January & 19 & 28 & 11.2 & 70 \\
February & 20 & 30 & 55.5 & 79 \\
March & 24 & 32 & 13 & 79 \\
April & 26 & 32 & 113.4 & 79.5 \\
May & 27 & 33 & 84.2 & 86 \\
June & 28 & 33 & 373.3 & 85 \\
July & 26 & 30 & 276.5 & 84 \\
August & 26 & 31 & 295.2 & 80 \\
September & 26 & 33 & 175.3 & 75 \\
October & 24 & 32 & 0 & 78.5 \\
November & 21 & 30 & 5.9 & 74 \\
December & 18 & 29 & 1403 & \\
Total & & & & Sources: IMD (Pune)
\end{tabular}

\section{Morphological characteristics}

The solum depth varied from (Table 3) moderately deep $(75-100 \mathrm{~cm})$ to very deep $(>150 \mathrm{~cm})$. The soils are well to somewhat excessively drained. The soil colour varied, from strong brown (7.5YR 4/6) on surface and dark reddish brown (2.5 YR 3/4) in subsurface soils (Jharokuali) whereas yellowish red (5YR 4/6) on surface and dark reddish brown (2.5 YR 3/4) to dark red (2.5 YR 3/6) in subsurface soils (Kumardaapalli) and dark reddish brown (5 YR 3/4) and dark grayish brown (10 YR 4/2) were distributed in entire pedons (Ranibara \& Kantiagada). These variations in soil colour appear to be the function of chemical and mineralogical composition as well as textural make up of soils and conditioned by topographic position and moisture regime (Walia and Rao 1997). The soils of foothills have occurrence of gravels at different depth of pedons 1 and 3 . The wide variation in gravel distribution might be due to variation in parent material, topography and in situ weathering process (Leelavathi et al. 2009). The structure of the soils is sub-angular blocky and single grain. The structure of sub-angular blocky was attributed to the presence of higher quantities of clay fraction (Sharma et al. 2004). The single grain structure of the soils (Kantiagada) was due to nearness to seashore. The consistence of the soils is soft to slightly hard (dry), very friable to friable (moist) and non-sticky to slightly sticky and non-plastic to slightly plastic (wet). Pedons 1, 2 and 3 showed thin or thick patchy cutans and also had argillic (Bt) sub-surface diagnostic horizons. Whereas, Kantiagada series do not have any diagnostic horizons due to sandy nature and classified as Typic Ustipsamments. Similar results were also reported by Basavaraju et al. (2005).

\section{Physical characteristics}

The detailed physical characteristics of the soils are presented in Table 3. Granulometric data revealed that the sand, silt and clay contents varied for each series. Sand content varied from 44.7 to $95.4 \%$ and the maximum was observed in Kantiagada series. Sand constituted the bulk of mechanical fractions, which could be attributed to the dominance of alluvium parent material. The silt is having very negligible level of presence in all the series and clay content is varied from 2.5 to $46.2 \%$. The vertical distribution of clay shown in pedon 1,2 and 3 increased from top to lower horizons. The increase in clay content in Bt horizons could be attributed to vertical translocation of clay. Similar results were reported by Srinivasan et al. (2013). 
Table 3. Morphological and physical characteristics

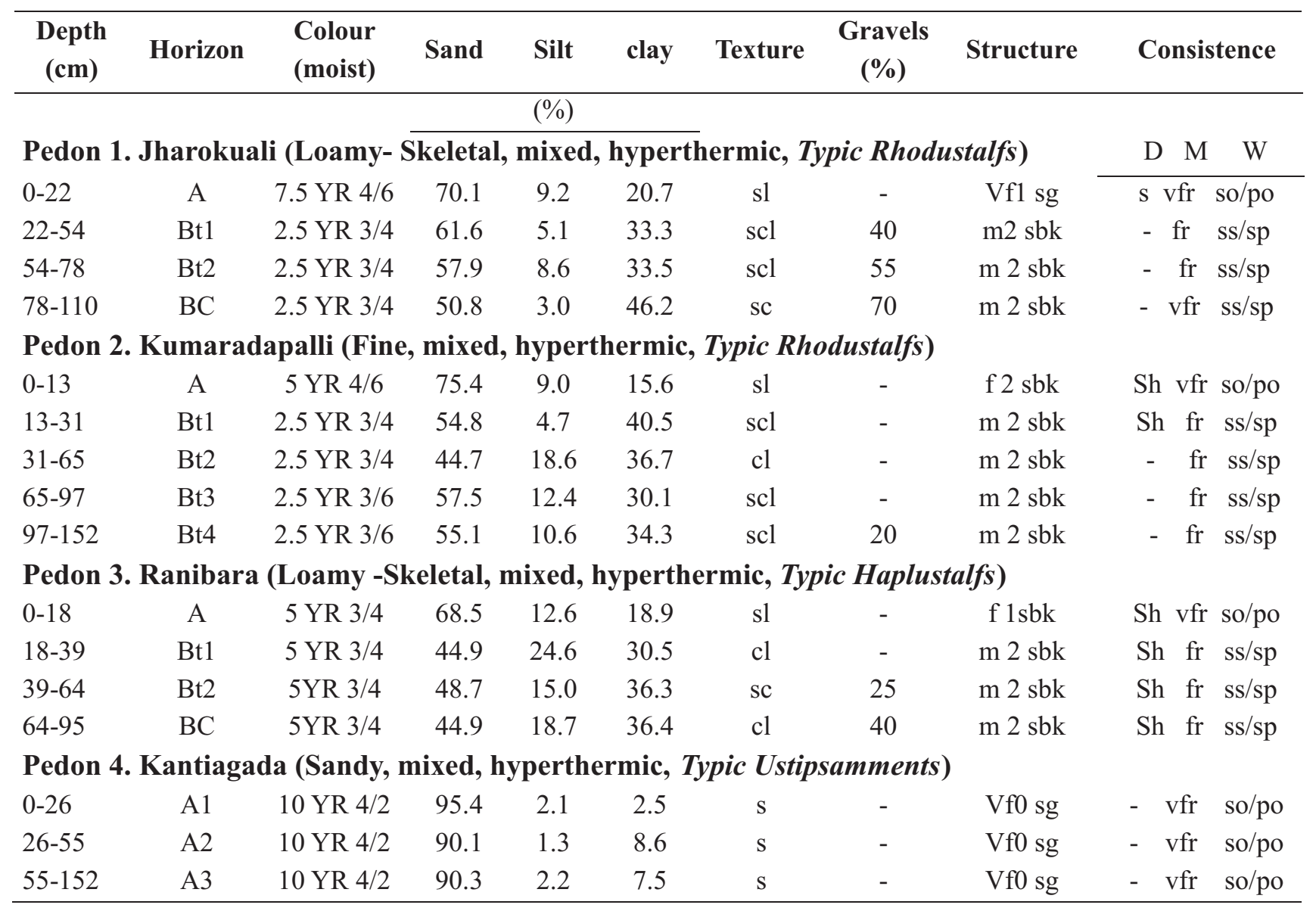

Texture: cl- clay loam,sl- sandy loam, scl - sandy clay loam, sc - sandy clay, s- sand,

Structure: Size (S) - vf - very fine, f - fine, m - medium, c - coarse; Grade (G) - 0 - structureless, 1- weak, 2 - moderate;

Type (T) sg - single grain, sbk - sub-angular blocky.

Consistence: Dry: s - soft, sh - slightly hard, Moist: fr - friable, vfr - very friable; Wet: so - non-sticky, ss - slightly sticky;

po - non-plastic, sp - slightly plastic.

\section{Physico-chemical characteristics}

Physico-chemical characteristics of the soils are presented in Table 4. Soils of pedons 1, 2 and 3 were slightly acidic to neutral (pH 5.5 to 6.8 ), whereas pedon 4 was slightly alkaline ( $\mathrm{pH} 7.7$ to 7.9 ). All the soils showed very low electrical conductivity values ranging from 0.03 to $0.46 \mathrm{dS} \mathrm{m}$ ${ }^{1}$ indicating very low amount of soluble salts. Organic carbon (OC) content of the soils was low to high (0.01 to $0.94 \%)$. The OC content decreased with the depth of the soils except pedon 3. This could be attributed to the addition of plant residues and farmyard manure to surface horizons than in the lower horizons. Therefore, the organic matter content has to be substantially increased through effective crop residue management (Chaudhary et al. 2008). CEC and base saturation was more in Pedon 1, 2, 3 and varied from 2.4 to $23.9 \mathrm{c} \mathrm{mol}\left(\mathrm{p}^{+}\right) \mathrm{kg}^{-1}$ and 58 to $86 \%$ respectively, whereas, pedon 4 had CEC and base saturation varied from 1.0 to $1.3 \mathrm{c}$ $\mathrm{mol}\left(\mathrm{p}^{+}\right) \mathrm{kg}^{-1}$ and 90 to $92 \%$. 


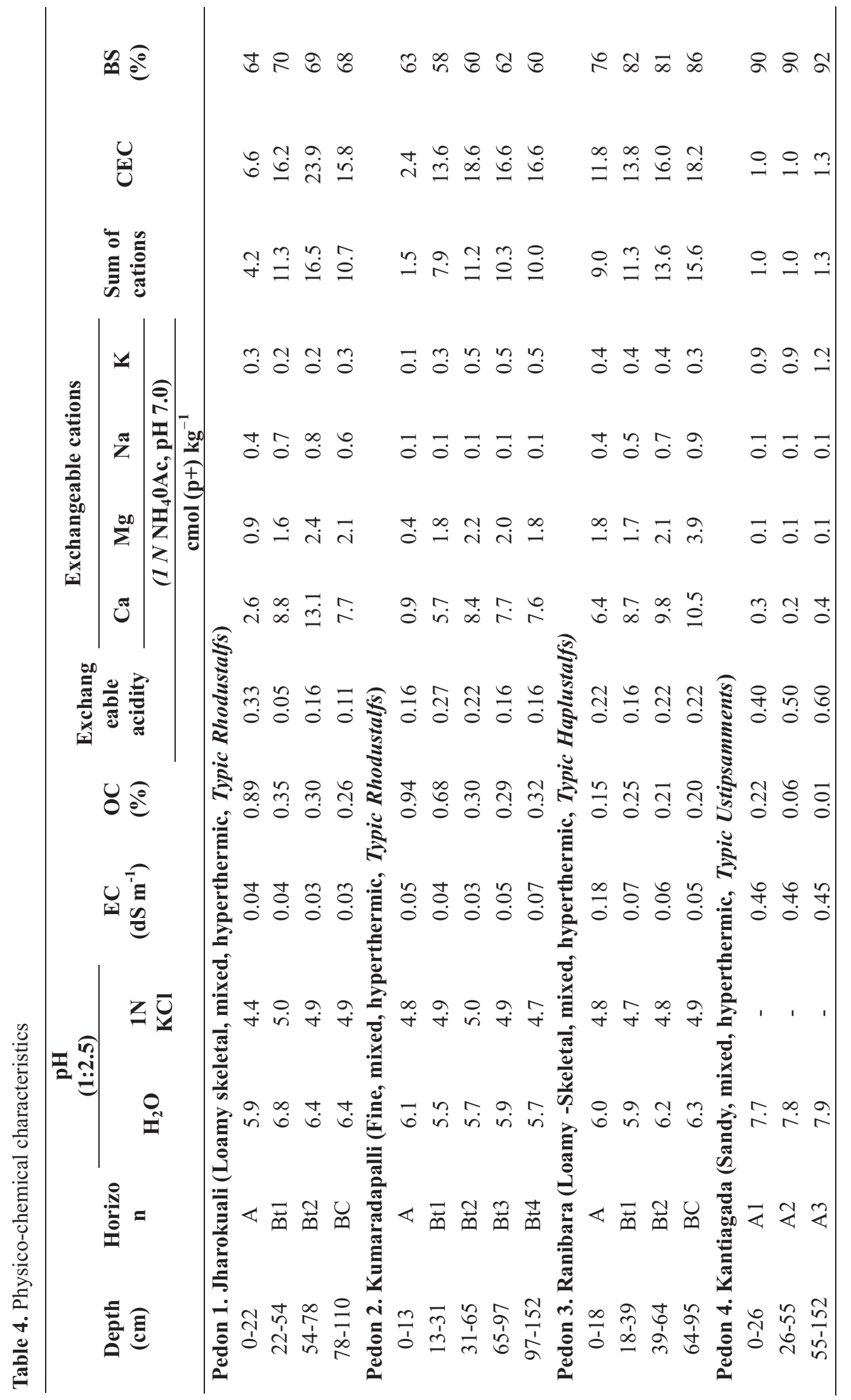


The low CEC of the soils could be due to dominance of Kaolinitic mineralogy. Exchangeable bases in all pedons were in the order of $\mathrm{Ca}^{2+}>\mathrm{Mg}^{2+}>\mathrm{Na}^{+}>\mathrm{K}^{+}$on the exchange complex. Exchangeable cations were low in Pedon 4.

\section{Plant Nutrient Status}

The available nitrogen content (Table 5) varied from 58 to $226 \mathrm{~kg} \mathrm{ha}^{-1}$ throughout the soil depth of the profiles, which is rated as low. However, available nitrogen content was found as high in surface horizons and decreased regularly with depth due to addition of litter falls on surface (Satish Kumar and Naidu 2012). Overall N status was low due to poor management.

Table 5. Nutrient status of the soils

\begin{tabular}{ccccccccc}
\hline & \multicolumn{7}{c}{ Macronutrients } \\
\cline { 3 - 8 } Depth (cm) & Horizon & $\mathrm{N}$ & $\mathrm{P}_{2} \mathrm{O}_{5}$ & $\mathrm{~K}_{2} \mathrm{O}$ & $\mathrm{Fe}$ & $\mathrm{Mn}$ & $\mathrm{Cu}$ & $\mathrm{Zn}$ \\
\cline { 3 - 8 }$\left(\mathrm{Kg} \mathrm{ha}^{-1}\right)$ \\
\cline { 3 - 8 }
\end{tabular}

The available phosphorus $\left(\mathrm{P}_{2} \mathrm{O}_{5}\right)$ status varied from 4.3 to $57.7 \mathrm{~kg} \mathrm{ha}^{-1}$. High available $\mathrm{P}$ content was observed in the pedon 1 and rests of the pedons were rated as low P. The available P content was decreased with increasing soil depth. The lower phosphorus content in sub-surface horizons as compared to surface horizon was due to the fixation of released phosphorus by clay minerals and oxides of iron and aluminium (Chandra Sekhar et al. 2014).

Available potassium $\left(\mathrm{K}_{2} \mathrm{O}\right)$ content varied from 28 to $664 \mathrm{~kg} \mathrm{ha}^{-1}$. The high available potassium content was observed in pedon 2 followed by pedons 1,3 and 4 . The distribution of available $\mathrm{K}$ with different depths was not consistent due to deposition of minerals from sea shores at different periods (Bandyopadhyay et al. 1985). 
The DTPA-extractable Fe content varied from 2.6 to $35.9 \mathrm{mg} \mathrm{kg}^{-1}$ respectively. According to the critical limit of $4.5 \mathrm{mg} \mathrm{kg}^{-1}$ (Lindsay and Norvell 1978), the soils were sufficient in available iron. The distribution of available iron in all the pedons did not show a definite pattern. The surface horizons contained more available Fe than sub-surface horizons. It might be due to accumulation of organic carbon in the surface horizons. The organic carbon due to its ability to influence the solubility and availability of iron by chelation effect might have protected the iron from oxidation and precipitation, which consequently increased the availability of iron (Vijaya Kumar et al. 2013).

The DTPA-extractable copper ( 0.14 to $3.40 \mathrm{mg} \mathrm{kg}$ ${ }^{1}$ ) and manganese (1.7 to $101.2 \mathrm{mg} \mathrm{kg}^{-1}$ ) were found to be sufficient in all the soils of the study area as these nutrients are well above their critical limits of 0.2 and $1.0 \mathrm{mg} \mathrm{kg}^{-1}$ respectively. The higher concentrations of available copper and manganese might be due to higher biological activity and the chelating of organic compounds, released during the decomposition of organic matter from leaves debris (Verma etal. 2005).
The DTPA extractable $\mathrm{Zn}$ ranged from 0.35 to 1.06 $\mathrm{mg} \mathrm{kg}{ }^{-1}$ in surface and 0.12 to $0.83 \mathrm{mg} \mathrm{kg}^{-1}$ in subsurface horizons. Vertical distribution of $\mathrm{Zn}$ exhibited varying trend with depth. Considering $0.6 \mathrm{mg} \mathrm{kg}^{-1}$ as critical level, the surface soils are sufficient in $\mathrm{Zn}$ except pedon 3. Overall, other micronutrients statuses of cashew soils are sufficient in surfaces horizons and deficient in few sub-surface horizons.

\section{Interpretative groupings}

Soils were interpreted to categorize into different themes like Land capability, Land irrigability and Suitability to Cashew considering climatic conditions, soil depth, texture, drainage, slope, presence of gravel, acidity and salinity levels. Land capability assessment categorized these soils into Class II -IV with limitations of erosion, drainage and soil limitations (Table 6). On the other hand, these soils were grouped into 2 to 4 . Land irrigability classes with limitations of texture and drainage. Land suitability assessment categorized these soils into highly to moderately suitable (Table 5) to grow Cashew. Major constraints encountered are soil erosion, wind erosion, poor soil fertility. Appropriate soil and water conservation measures, strip cropping, shelter belts and addition of tank silt and organic manures are suggested to overcome the limitations and improving the productivity of Cashew. 
R. Srinivasan et al.

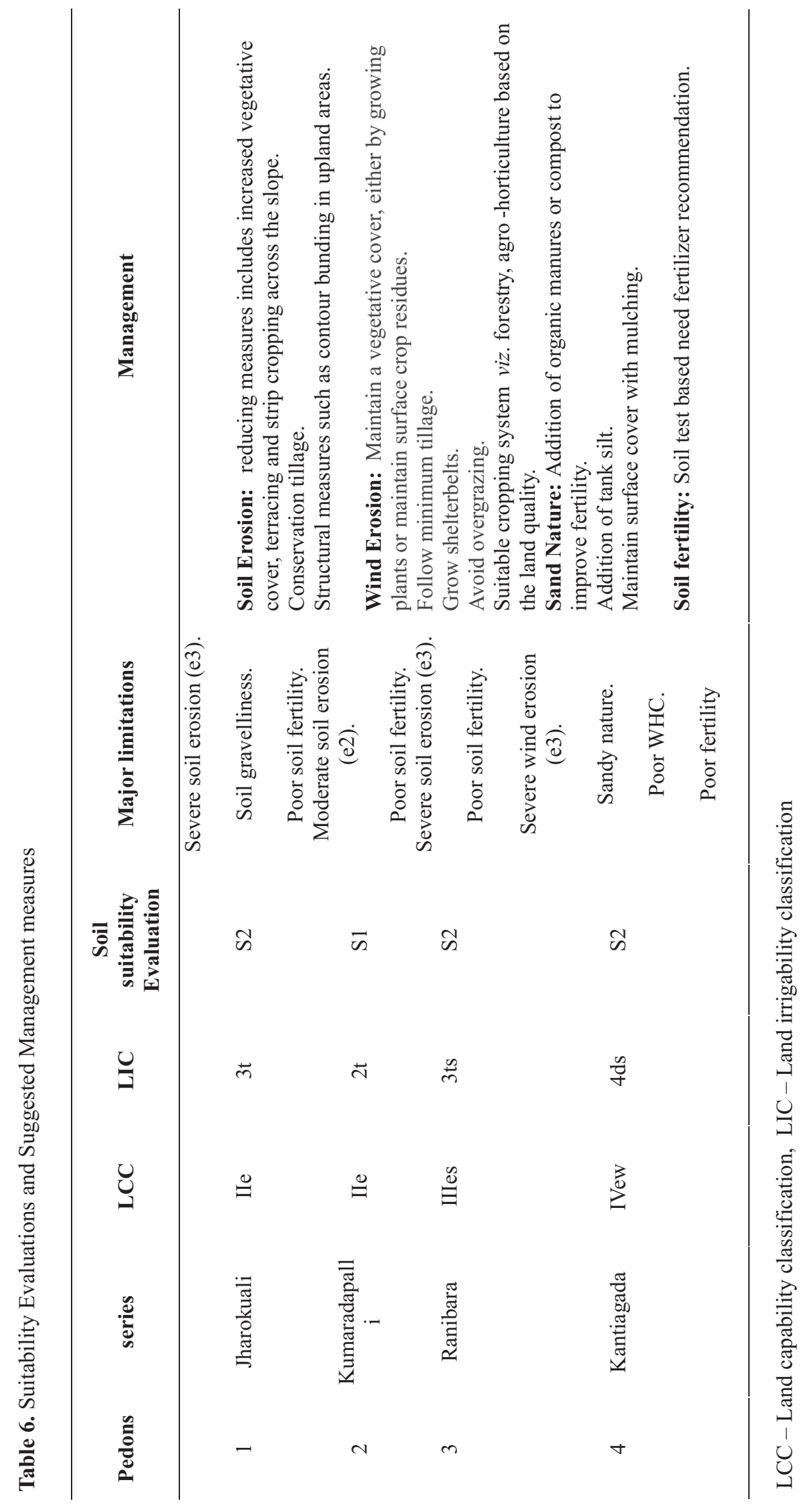




\section{Conclusions}

The soil survey investigations of cashew growing soils of coastal Odisha revealed that the soils were slightly acidic to moderately alkaline in reaction with low in organic carbon. The $\mathrm{CEC}$ was low to medium and exchange bases are dominated by $\mathrm{Ca}^{2+}$. Soil available nitrogen was low where as available phosphorus and potassium was low to high. The soils were sufficient in DTPA-extractable micronutrients except zinc which was sufficient in surface horizons and deficient in sub-surface horizons. Soils were categorized as highly to moderately suitable for Cashew production. Appropriate soil and water conservation and agronomic management measures are suggested to overcoming soil related constraints for improving cashew productivity.

\section{References}

AIS\&LUS. (1970). Soil Survey Manual, All India Soil and Land Use Survey Organisation, IARI, New Delhi, pp. 1-63.

Bandyopadhyay, B.K., Bandyopadhyay, A.K. and Bhagava, G.P. (1985). Characterization of soil potassium and quality intensity relationship of potassium in some coastal soils. Journal of Indian Society of Soil Science 3, 548-554.

Basavaraju, D., Naidu, M.V.S., Ramavatharam, N., Rao, K.G.R. and Reedy, K.S. (2005). Characterization, classification and evaluation of soils in Chandragiri mandai of Chittoor district, Andhra Pradesh. Agropedology 15, 55-62.

Bray, R.H. and Kurtz, L.T. (1945). Determination of total, organic and available forms of Phosphorous in soils. Soil Science 59, 39-45.

Chandra Sekhar, Ch., Balaguravaiah, D. and Naidu, M.V.S. (2014). Studies on genesis, characterization and classification of soils in central and Eastern parts of Prakasam district in Andhra Pradesh. Agropedology 24 (02), 125-137.

Chaudhary, D.R., Ghosh, A. and Boricha, N. (2008). Characterization and classification of coastal saline soils of Paradip, Orissa. Agropedology 18, 129-133.

George, H. (2005). An Overview of Land Evaluation and Land Use Planning at FAO, FAO, Rome, Italy.

Ghosh, S.N. and Bose, T.K. (1986). Nutritional requirement of cashew (Anacardiumoccidentale L.) in the laterite tract of West Bengal. Indian Cashew Journal 18, 11-16.
Jackson, M.L. (1973). Soil Chemical Analysis, Prentice-Hall of India Pvt. Ltd. New Delhi, pp. 40.

Leelavathi, G.P., Naidu, M.V.S., Ramavatharam, N. and Karuna Sagar, G. (2009). Studies on Genesis, Classification and Evaluation of Soils for Sustainable Land Use Planning in Yerpedu Mandal of Chittoor District, Andhra Pradesh. Journal of the Indian Society of Soil Science, 57 (2), 109-120.

Lekwa, M.U., Anene, B.O. and Lekwa, G. (2004). Chemical and morphological soil characteristics in drainage toposequence in southeastern Nigeria. Proceedings of the 28th Annual Conference of the Soil Science Society of Nigeria, November 4-7, Umudike, Abia State, pp:316-322.

Lindsay, W.L. and Norvell, W.A. (1978). Development of DTPA soil test for zinc, iron, manganese and copper. Soil Science Society of America Journal 42, 421-428.

Naidu, L.G.K., Ramamurthy, V., Challa, O., Rajendra Hegde. and Krishnan, P. (2006). Manual soil-site suitability criteria for major crops. NBSS\&LUP Pub. No.129: 66-67.

Page, A.L., Miller, R.H. and Keeney, D.R. (1982). Methods of Soil Analysis, Part 2, 2nd ed., Soil Science Society of America, Madison, USA.

Sarma, V.A.K., Krishnan, P. and Budihal, S.L. (1987). Laboratory methods. NBSS pub.14, Technical Bulletin, National Bureau of Soil Survey and Land Use Planning, Nagpur, pp 49.

Satish Kumar, Y.S. and Naidu, M.V.S. (2012). Characteristics and classification of soils representing major landforms in Vadamalapeta mandal of Chittoor district, Andhra Pradesh. Journal of the Indian Society of Soil Science 60, 6367.

Sharma, S.S., Totawat, K.L. and Shyampura, R.L. (2004). Characterization and classification of salt-affected soils of southern Rajasthan. Journal of the Indian Society of Soil Science 52, 209-213.

Soil Survey Staff. (2010). 'Keys to Soil Taxonomy', Eleventh Edition. (U.S.D.A.: Washington, D.C.).

Srinivasan, R., Natarajan, A., Anil Kumar, K.S. and Kalaivanan, D. (2013). Characterization of major Cashew Growing Soils of Dakshina Kannada District of Karnataka. Agropedology 23 (2), 59-64.

Subbaiah, B.V. and Asija, G.L. (1956). A rapid procedure for estimation of available nitrogen in soils. Current Science 25, 259-260. 
Udoh, B.T. (2015). Suitability of soils derived from sandstone and beach sands for cashew (Anacardiumoccidentalis) and coconut (Cocos nucifera) cultivation in the Niger Delta Area, Nigeria. Sky Journal of Soil Science and Environmental Management 4 (2), 27-33.

Verma, V.K., Setia, R.K., Sharma, P.K., Singh Charanjit. and Ashok Kumar. (2005). Micronutrient distribution in soils developed on different physiographic units of Fatehgarh Sahib district of Punjab. Agropedology 15, 70-75.
Vijaya Kumar, M., Lakshmi, G.V. and Madhuvani, P. (2013). Appraisal of soil fertility in salt-affected soils of Ongole division, Prakasam district, Andhra Pradesh. Journal of the Indian Society of Soil Science 61, 333-340.

Walia, C.S. and Rao, Y.S. (1997). Characteristics and classification of some soils of Trans-Yamuna plains. Journal of the Indian Society of Soil Science 45, 156- 162.

Walkley, A. and Black, I.A. (1934). An examination of the Degtjareff method for determining soil organic matter and a proposed modification of the chromic acid titration method. Soil Science 37, 29-38.

Received: September 2016 Accepted: December 2016 